\title{
COVID-19 PANDEMIC'S IMPACT ON THE LABOUR MARKET IN ASEAN COUNTRIES
}

\author{
Li Jingyi ${ }^{a^{*}, \text { Beatrice } \text { Lim }^{b}, \text { Khairul Hanim Pazim }}{ }^{b}$ and Fumitaka Furuoka ${ }^{a}$ \\ ${ }^{a}$ Asia-Europe Institute, University of Malaya \\ ${ }^{b}$ Faculty of Business, Economics and Accountancy, Universiti Malaysia Sabah \\ *Corresponding author: 17198907@siswa.um.edu.my
}

\begin{abstract}
This paper aims to examine the impact of the COVID-19 pandemic on the labour market in ten ASEAN countries, namely Brunei, Lao PDR Cambodia, Indonesia, Malaysia, the Philippines, Myanmar, Singapore, Vietnam and Thailand. A flu virus first detected in China later affected neighbouring Southeast Asian countries. Although the pandemic has varying implications and at varying levels, it has a negative impact on the ASEAN economies. The labour market is affected as economic activities came to a halt when ASEAN governments-imposed lockdowns or restricted movement. Job losses continue to escalate amid the pandemic, vulnerable workers such as those working in informal sectors, self-employed workers, gig workers, migrant workers, and micro, small and medium enterprises are facing a tough labour market and also at risk of losing livelihood due to lockdown. Post-COVID-19, ASEAN region sees the need for collective action to build the economy, leveraging on technology and digital trade. The pandemic may reshape ASEAN's digital landscape in the labour market especially on the way work is done in the future.
\end{abstract}

Keywords: COVID-19, labour market, pandemic, ASEAN

\section{Introduction}

On 31 December 2019, a novel coronavirus in Wuhan City, Hubei Province, was reported to the World Health Organization (WHO) China Country Office (WHO, 2020). The virus has quickly become a far greater global health crisis than the Severe Acute Respiratory Syndrome Coronavirus (SARS-CoV) of 2003 and the Middle East Respiratory Syndrome Coronavirus (MERS-CoV) of 2012(Li, Liu, Yu, Tang, \& Tang, 2020). On 30 January 2020, the WHO stated the new virus as a public health emergency (Zhang \& Shaw, 2020). The International Committee for the Taxonomy of Virus (ICTV) on 11 February 2020 described the new virus as a serious acute coronaviral syndrome (SARS-CoV-2) currently referred to as "COVID-19" by the WHO (Sharma, Tiwari, Deb, \& Marty, 2020). Coronavirus disease has been declared a global pandemic by the World Health Organization (WHO) on 11 March 2020. (Li et al., 2020). 


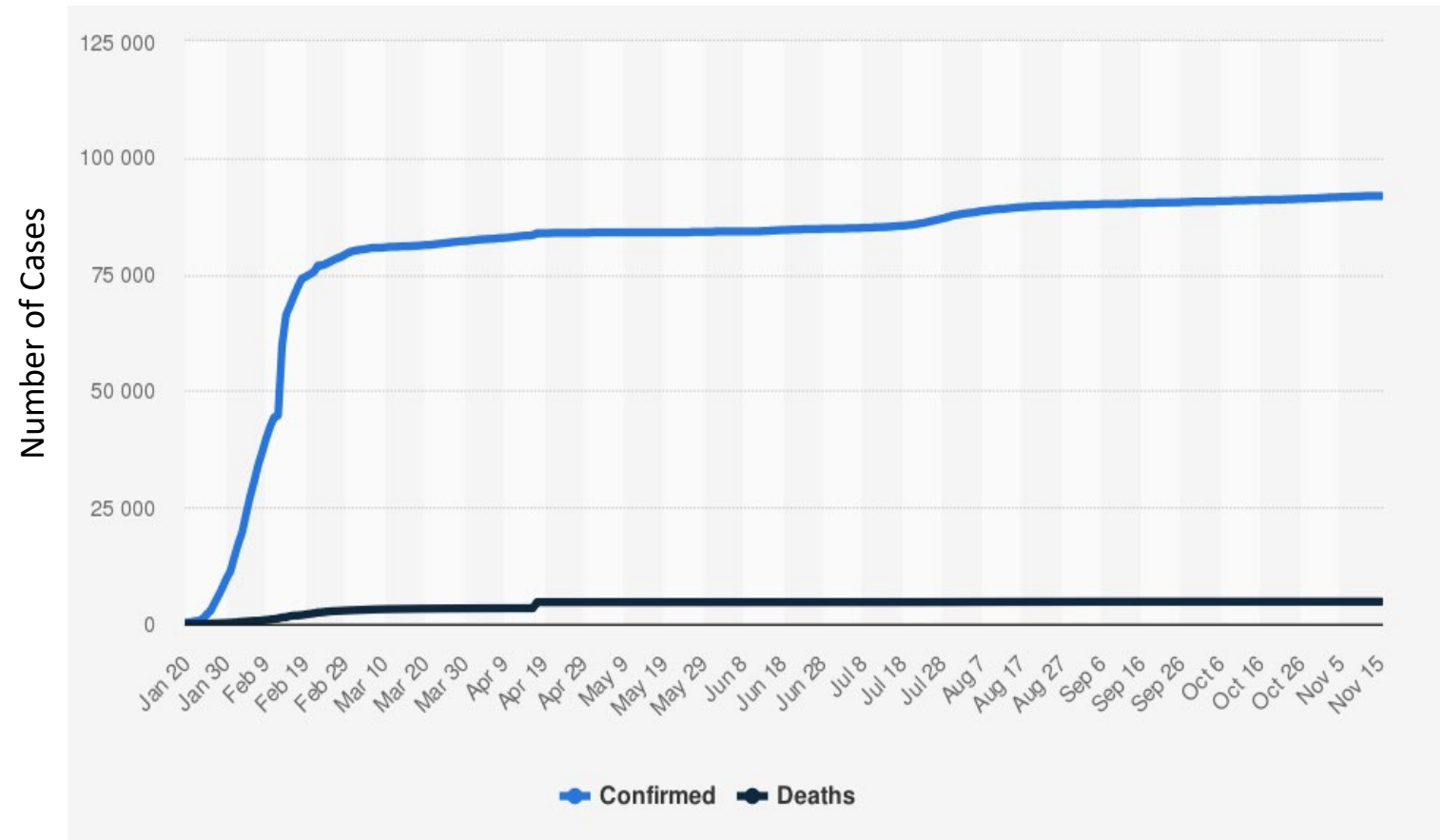

Source: Statista (2020)

Figure 1: Number of novel coronavirus COVID-19 cumulative confirmed and death cases in China (January 20 November 15, 2020)

Figure 1 shows that the COVID-19 cumulative number of confirmed cases and deaths in China from 20 January to 15 November 2020. The COVID-19 has infected 91,800 people. 4742 people have died from COVID-19 until 15 November of 2020 in China (Statista, 2020).

On 7 June 2020, a white paper titled "Fighting COVID-19: China in Action" was released by the China's State Council Information Office to present its prevention, control, treatment efforts in battling COVID-19 and China's cooperation with the international community (Chinadaily, 2020). Not only does the document contain the efforts and experiences of China in the fight against the pandemic, but it also provides recommendations for other countries on how to win over the coronavirus (Kobierski, 2020).

According to the white paper, there are five stages that China's fight against the COVID-19. The first stage is "swift response to the public health emergency from 27 December 2019 to 19 January 2020": China immediately took action to carry out etiological and epidemiological investigations after unknown pneumonia cases were identified (SCIO, 2020). The second stage is "initial progress in containing the virus from 20 January to 20 February 2020": due to the rapidly increasing confirmed cases, the Chinese government conducted a crucial step that closed Wuhan's outbound traffic to stem the virus's spread (SCIO, 2020). The third stage is "newly confirmed domestic cases on the Chinese mainland drop to single digits from 21 February to 17 March 2020": the Central Committee of the Communist Party of China made a significant decision to coordinate COVID-19 prevention and control with economic and social development, and orderly resumed work and daily life to minimize the losses caused by COVID-19(SCIO, 2020). The fourth stage is "Wuhan and Hubei - an initial victory in a critical battle from 18 March to 28 April 2020" : the spread of the national pandemic with Wuhan as 
the main battleground was halted(SCIO, 2020). The restrictions for Wuhan City and Hubei Province were lifted, and all Wuhan's hospitalized patients with COVID-19 were discharged. The fifth stage is "ongoing prevention and control since 29 April 2020": domestic virus and inbound cases are generally under control (SCIO, 2020). China has made arduous efforts to resume work and reopen schools, and achieved a major strategic success in the nationwide control efforts (SCIO, 2020).

As the end of the April, industrial enterprises (99\%), small and medium-sized enterprises $(88.4 \%)$, and construction projects $(95 \%)$ nationwide had resumed; while the resumption rate of enterprises and the return to work rate had reached $98.2 \%$ and $92.1 \%$ respectively in Hubei Province (SCIO, 2020). Thus, China's economic operation is gradually returning to normal (Chinadaily, 2020)..

\section{COVID-19 Pandemic in ASEAN}

Southeast Asia was one of the first regions affected due to its close geographical proximity and business travel, tourism and supply chain links to China. The first COVID-19 case was reported in Malaysia on 25 January 2020, prior to the upward swing of cases at the end of February 2020. (Tang 2020). The number of cases remained low and were confined to imported cases until localised cluster began in March 2020.

Table 1: COVID-19 Cases in ASEAN as at 30 September 2020

\begin{tabular}{|l|l|l|l|l|l|}
\hline & Cases & Deaths & Tests & Recovered & $\begin{array}{l}\text { Cases } \\
\text { millions }\end{array}$ \\
\hline World & $\mathbf{3 3 , 4 1 7 , 3 8 6}$ & $\mathbf{1 , 0 0 2 , 6 7 6}$ & - & $\mathbf{2 3 , 1 9 3 , 2 3 8}$ & $\mathbf{4 , 2 8 4}$ \\
\hline China & 90,509 & 4,739 & - & 85,415 & 63 \\
\hline USA & $7,150,824$ & 205,091 & $102,342,416$ & $2,794,608$ & 21,604 \\
\hline Indonesia & 282,724 & 10,601 & $1,962,754$ & 210,437 & 1,055 \\
\hline Philippines & 309,303 & 5,448 & $3,680,659$ & 252,930 & 2,949 \\
\hline Vietnam & 1,094 & 35 & 261,004 & 1,007 & 11 \\
\hline Thailand & 3,559 & 59 & 849,874 & 3,370 & 51 \\
\hline Myanmar & 11,631 & 256 & 253,704 & 3,073 & 218 \\
\hline Malaysia & 11,135 & 134 & $1,510,390$ & 9,939 & 357 \\
\hline Cambodia & 277 & 0 & 10,438 & 275 & 17 \\
\hline Lao PDR & 23 & 0 & 51,882 & 22 & 3 \\
\hline Singapore & 57,742 & 27 & $2,692,047$ & 57,393 & 10,289 \\
\hline Brunei & 146 & 3 & 29,841 & 142 & 341 \\
\hline
\end{tabular}

Source: CSIS Southeast Asia Program, https://www.csis.org/programs/southeast-asia-program/southeast-asiaCOVID-19-tracker-0, accessed on 30 September 2020. 
The active cases in Malaysia declined from a peak of 2,596 in early April to less than 250 cases by late June. The highest number of cases was recorded in the Philippines by the end of September, followed by Indonesia, Singapore and Myanmar. The pandemic is less serious in Thailand, Cambodia, Lao PDR, Vietnam and Brunei. (Table 1).

The Malaysian Government imposed a nationwide Movement Control Order (MCO) intended to flatten the infection curve and to reduce burden on the health care system. Between 18 and 31 March, the public was encouraged to stay at home. All schools from kindergarten to higher education institutions, as well as government and private premise were temporarily closed for two weeks. Essential services, such as water, power, electricity, telecommunications, oil, gas fuel, broadcasting, finance, banks, health, pharmacy, defence, defence, food and retail services, remain available. The MCO was extended by two weeks until 14 April as there were still large numbers of new cases. The MCO has been extended further to 28 April 2020 and to 12 May 2020. During these periods, employees were encouraged to work from home. However, workers in the service sector and other sectors that require workers to be physically present at work to complete their jobs were severely affected. Several stimulus packages have been launched in Malaysia, including electricity discounts, employee monetary assistance schemes, direct cash payments to 4 million low-income households, wage subsidies, SME grants and loans and tax deductions. (The discussion in this paragraph and the following is drawn heavily from the Center for Strategic and International Studies (CSIS) 2020).

A widespread testing, detailed contact tracking and a mandatory well-implemented quarantines were used to avoid the virus in the neighbouring country, Singapore. However, in April, the city-state experienced a surge of cases involving dormitories of foreign employees. New community infections continue at a lower rate. A 'circuit breaker', similar to the MCO in Malaysia, was implemented on 7 April 2020 to ensure the public to stay at home. The 'circuit breaker' was later extended to 1 June 2020. Singapore reopened schools and $75 \%$ of its economy gradually, allowing one-third of employees to return to their work in offices and factories from 2 June 2020. Students from elementary school, secondary school and junior high school returned daily from 29 June 2020.

The Singapore government announced multiple stimulus packages, namely the one-off payments to citizens, wage subsidies, and relief funds to self-employed workers. As part of a workfare income supplement scheme aimed at assisting the bottom 20 percent of the workforce, about 400,000 low-income employees were eligible for cash pay-outs starting on 28 July 2020. A 33-million-dollar campaign was launched by the Singapore Tourism Board to support domestic tourism and redirect foreign spending. The government has spent about 70.4 billion dollars (approximately 20\% of GDP) before April in response to the COVID-19. The expenditure was Asia's most extensive and most combative stimulus package. Eventually, in August 2020, Singapore and Malaysia began to reopen their country borders permitting limited business travel among their citizens.

In Indonesia, the government declared an "Emergency of Public Health" on 31 March 2020 enabling regional governments to impose social restrictions such as closing schools and offices and restricting the holding of religious and public meetings. The implementation of quarantines and lockdowns varied considerably, depending on the location. Jokowi unveiled a five-point plan on 4 May 2020 to foresee the second wave of the pandemic: (1) The Large-Scale Social Restriction Evaluation; (2) testing, contact tracking and isolation goals for provinces under the 
Large-scale Social Restriction; (3) regulation of migrant workers more rigorously ; (4) Stronger social security net for families with low incomes; and (5) a feedback hotline about pandemic management by the government. The WHO has put pressure on Jakarta due to its low testing rates compared to other countries worldwide.

With the increased numbers of casualties and deaths, local leaders began to reimpose lockdowns, particularly in Jakarta. The "New Normal" policy of President Jokowi states that touristic destinations are witnessed by thousands of local visitors, with social and religious activities unchecked. The country seems to abandon flattening its curve in favour of economic reopening. Still, official governments and international sources have confirmed that the economy continues to contract, irrespective of whether it is. In addition to strengthening the social safety nets, the government launched some incentive packages to support low-income families, micro-enterprises, and state-owned businesses.

The Philippines recorded the highest number of cases in ASEAN by the end of September 2020. Most restrictions were lifted on 1 June 2020, after 76 days, causing a massive rise of COVID-19 cases. Threatening the public health system, the economic situation of the country continues to worsen. While social mobility constraints and testing have steadily increased across the country, the government is still controlling the virus. The Philippines government has announced a social protection programme for low-income families and health workers, similar to other ASEAN countries. Approximately 3.4 million micro-businesses benefited from a Wage Subsidy Package. President Duterte also adopted a pandemic relief measure of $\$ 3.4$ billion to expand healthcare and support to small businesses on 11 September 2020. However, the country continues to be hit by protests against the lack of food and job loss.

The battle against COVID-19 was relatively well-conducted in Thailand with fast lockdown, effective test \& tracking and with the already strong health systems. However, Thailand reported a new case on 3 September 2020, after over 100 days without local transmission. Prime Minister Prayuth declared the first state of emergency on 26 March2020 until the end of August, although lockout action was relaxed on 29 June2020 for most businesses. Thailand is also expected to be hit hardest economically because of its intense dependence on tourism and exports sector. Thailand declared in September 2020 that it will spend up to 1 billion to help its agricultural sector and build rural employment. The government also announced plans for a new $\$ 58$ billion stimulus package in funding for workers, infrastructure and job investments, soft loans to SMEs and the Stabilization Fund for Corporate Bond Bonds.

Vietnam was initially able to successfully control the pandemic, despite scarce resources and a busy frontier with China. The first local quarantine orders in Vietnam were declared on 15 February 2020 while the national lockdown commenced on 1st April 2020. On 25 April 2020, the government issued guidelines authorising localities to remove COVID-19 restrictions when the virus had been contained. Prime Minister Nguyen Xuan Phuc declared in March 2020 that he would provide the government with a fiscal stimulus package of $\$ 1.16$ billion. The package included tax breaks, deferred tax payments and government infrastructure investment. Furthermore on 24 March 2020 Vietnam also halted stopped rice export to ensure national food safety. Though Vietnam was hit by a second wave spread from Danang City, the COVID-19 was under control at the beginning of September. 
The ASEAN region's lowest case counts were held by Myanmar until August 2020. But the number of cases soared sharply thereafter, primarily due to the pandemic in Rakhine State which has spread across the largest cities of Myanmar. In the event of an escalating wave of infections, the under-developed health care system in Myanmar may not be able to cope with the pandemic. In addition, the on-going targeting of the internet ban may lead to some conflicting regions of Myanmar not being aware of the pandemic. Other measures to contain the spread include extending the stay-at-home order and closing schools while businesses are permitted to remain open.

Despite poor healthcare infrastructures and an initially slow response, Cambodia reported few cases and zero casualties. This has contributed to a widespread speculation of inadequate counting of infections. The government declared the closing of schools throughout the country in March 2020. The Ministry of Education approved the reopening of kindergartens and elementary schools by August 2020. The government has already reopened places of worship, educational institutions and several industries with plans to revive the whole economy. Flights to several Chinese cities and some countries in Southeastern Asia have resumed in Cambodia.

Lao People's Democratic Republic, which is the Southeast Asia's most rural nation, was the last to announce its first COVID-19 infection. While the healthcare infrastructure is nearly nonexistent, the pandemic has been avoided. This can be explained in terms of geography and demography factors. The Lao People's Democratic Republic is sparsely populated and enclosed by residence who managed to relatively well contain this virus. Like its neighbouring countries, the Lao PDR economy has also been affected despite minimal cases reported. However, Lao's PDR has already resumed travel to many Southeast Asian countries and fostered domestic tourism to improve its economy.

The economies of ASEAN were further affected by China's supply and trade disruptions and by the dramatic drop in foreign tourism, where many countries have taken lockout and social containment action (OECD 2020). Among the most affected are SMEs, services and the tourism industry. Governments of ASEAN have adopted incentives to minimise the economic impact (OECD 2020).

At a regional level, the 26th ASEAN Economic Ministers (AEM) retreat released a statement calling for concerted action to mitigate the effects of the virus, focusing on technology leveraging and digital commerce, as well as commercial facilitation mechanisms to promote connectivity in the supply chain and sustainability. It is hoped that a post-pandemic recovery plan and a proposed development of the COVID-19 ASEAN Response Fund will counteract social and economic effects in ASEAN (OECD 2020). Therefore, closer regional cooperation among ASEAN countries is particularly important in the post-COVID 19 period.

\section{General characteristics of the labour market in ASEAN countries}

It is interesting to note that there are huge discrepancies in term of geographic size, population and national income among ASEAN countries. Table 2 reports the land area, total population, Gross Domestic Product (GDP) and per capita GDP in these countries. Firstly, the total land area in ASEAN countries amounted to 4.6 million square $\mathrm{km}$. The largest country in term of the area in Indonesia (1.9 million square $\mathrm{km})$ while the smallest country is Singapore $(0.7$ 
thousand square $\mathrm{km}$ ). In term of land area, Indonesia is 2,720 times as large as Singapore. Secondly, the total population in ASEAN countries amounted to 656.3 million. Indonesia is the largest country in term of the population (267.6 million) while Brunei is the smallest country ( 0.4 million). Indonesia is 669 times as large as Brunei in term of population. Thirdly, the total GDP in ASEAN countries amounted to 3.2 trillion US dollars. Once again, Indonesia has the biggest national income (US\$1.2 trillion) while Brunei has the smallest national income (US\$13.3 million). In term of GDP, Indonesia is 90 time as large as Brunei. Finally, there are three ASEAN countries whose income per person are greater than US\$10,000, namely Singapore (US\$68,487), Brunei (US\$30,204) and Malaysia (US\$11,484). By contrast, there are four countries whose income per person is less than US\$3,000, namely Cambodia, Lao PDR, Myanmar and Vietnam. These countries are known as CLMV countries. The main objective of ASEAN economic policy is to stimulate economic growth in these CLMV countries to catch with richer ASEAN countries, such as Singapore, Brunei and Malaysia.

Table 2: Geographic size, population and income (2020)

\begin{tabular}{|l|l|l|l|l|}
\hline & $\begin{array}{l}\text { Land Area } \\
(1000 \text { square km) }\end{array}$ & $\begin{array}{l}\text { Total Population } \\
(\text { million })\end{array}$ & $\begin{array}{l}\text { GDP } \\
\text { (billion } \\
\text { dollars })\end{array}$ \\
\hline Brunei & 5.7 & 0.4 & 13.3 & $\begin{array}{l}\text { GDP per capita } \\
\text { (US dollars) }\end{array}$ \\
\hline Cambodia & 181.0 & 15.2 & 21.8 & 30,240 \\
\hline Indonesia & $1,904.5$ & 267.6 & $1,200.0$ & 1,614 \\
\hline Lao PDR & 237.9 & 7.1 & 20.1 & 4,460 \\
\hline Malaysia & 330.8 & 32.7 & 381.5 & 2,670 \\
\hline Myanmar & 676.5 & 52.5 & 66.1 & 11,484 \\
\hline Philippines & 300.0 & 109.0 & 383.3 & 1,245 \\
\hline Singapore & 0.7 & 5.7 & 391.3 & 3,484 \\
\hline Thailand & 513.1 & 69.9 & 516.0 & 68,487 \\
\hline Vietnam & 331.2 & 96.2 & 261.6 & 7,607 \\
\hline Total & $4,681.4$ & 656.3 & $3,255.0$ & 2,740 \\
\hline
\end{tabular}

Source: World Bank (2020)

Table 3 reports four types of labour force participation rate (LFPR), namely the total LRPR, the male LFPR, the female LFPR and the LFPR gap or the difference between male and female LFPR. The findings from the table also indicate that there is a considerable difference in the LFPR among ASEAN countries. Firstly, the average level of total LFPR in ASEAN countries is 64.5. There are two countries whose total LFPR are greater than 70, namely Cambodia (81.7) and Vietnam (76.2). By contrast, there are two countries whose total LFPR is less than 60, namely Lao (40.7) and the Philippines (58.9). Cambodia has the highest level of total LFPR while Lao has the lowest level of the total LFPR. In other words, Cambodia's total LFPR is 
almost 2 time as high as Lao's total LFPR. Secondly, the average level of male LFPR in ASEAN countries is 74.7. There are three countries whose male LFPR are greater than 80, namely Cambodia (88.0), Indonesia (82.2) and Vietnam (81.5). On the other hand, there are two countries whose male LFPR is less than 70, namely Lao (45.2) and Brunei (68.8). Cambodia has the highest level of the male LFPR while Lao PDR has the lowest level of the male LFPR. In other words, the difference in male LFPR between Cambodia and Lao PDR is 42.8. Thirdly, the average level of female LFPR in ASEAN countries is 61.1. There are two countries whose female LFPR are greater than 70, namely Cambodia (75.9) and Vietnam (71.2). Also, there are three countries whose female LFPR is less than 50, namely Lao (36.5), the Philippines (45.3) and Myanmar (48.4). Cambodia has the highest level of the female LFPR while Lao PDR has the lowest level of the female LFPR. In other words, difference in female LFPR between Cambodia and Lao PDR is 39.4. Finally, it should be noted that there are huge discrepancies in the LFPR gap among ASEAN countries. The LFPR gap is difference between male the LFPR and female LFPR. There are four countries whose LFPR gap is greater than 25, namely Indonesia (28.9), Myanmar (28.6), the Philippines (27.1) and Malaysia (25.3). Also, there are four countries whose LFPR gap is less than 15, namely Lao PDR (8.7). Vietnam (10.3), Cambodia (12.1) and Brunei (12.4). It means that Indonesia's LFPR gap is more than three times as high as Lao PDR's LFPR.

Table 3: Labour force participation rate (total, male, female and gap) (2020)

\begin{tabular}{|l|l|lr|l|l|}
\hline & $\begin{array}{l}\text { Labour force } \\
\text { participation rate } \\
\text { (total) }\end{array}$ & $\begin{array}{l}\text { Labour force } \\
\text { participation rate } \\
\text { (male) }\end{array}$ & $\begin{array}{l}\text { Labour force } \\
\text { participation rate } \\
\text { (female) }\end{array}$ & $\begin{array}{l}\text { Labour force } \\
\text { participation } \\
\text { rate (gap) }\end{array}$ \\
\hline Brunei & 62.7 & 68.8 & 56.4 & 12.4 \\
\hline Cambodia & 81.7 & 88.0 & 75.9 & 12.1 \\
\hline Indonesia & 67.7 & 82.2 & 53.3 & 28.9 \\
\hline Lao PDR & 40.7 & 45.2 & 36.5 & 8.7 \\
\hline Malaysia & 67.9 & 80.0 & 54.7 & 25.3 \\
\hline Myanmar & 61.4 & 77.0 & 48.4 & 28.6 \\
\hline Philippines & 51.9 & 72.4 & 45.3 & 27.1 \\
\hline Singapore & 67.7 & 75.6 & 60.2 & 15.4 \\
\hline Thailand & 67.7 & 76.5 & 59.6 & 16.9 \\
\hline Vietnam & 76.2 & 81.5 & 71.2 & 10.3 \\
\hline Average & 64.5 & 74.7 & 56.1 & 18.5 \\
\hline
\end{tabular}

Source: World Bank (2020)

Figure 2 depicts the relationship between income per person and four types of the LFPR, namely total LFPR, male LFPR and female LFPR and LFPR gap. Firstly, there is a weak positive relationship between GDP per capita and total LFPR in ASEAN countries. In other words, countries with higher income level would tend to have a higher total LFPR. For example, Singapore's total LFPR (67.7) is relatively higher than total LFPR in the Philippines 
(51.9) and Myanmar (61.4). There are two main outliers in this positive relationship, namely Cambodia (81.7) and Vietnam (76.2). This positive relationship could be explained by the level of technology. There are few high tech industries in Cambodia and Vietnam and these countries depend on the labour-intensive industries. As a sequence, there could be higher LEPR in these relatively poorer ASEAN countries. Among ASEAN countries, these countries are relatively poor. However, these countries have relatively higher total LFPR. Secondly, there is no clear linkage between income level and male LFPR. Despite huge discrepancies in income level, there is a minor difference in the male LFPR, except Lao PDR. The male LFPR in the richest ASEAN country, Singapore, is 75.6 while the male LFPR in the poorest ASEAN country, Myanmar, is 77.0. Lao PDR is the outlier in this relationship and its male LFPR is only 45.2. Thirdly, there also is a week positive relationship between income level and female LFPR in the region. It would mean that countries with higher per capita income would tend to have a higher female LFPR. For instance, Singapore's female LFPR (60.2) are relatively higher than other ASEAN countries, except Cambodia (75.9) and Vietnam (71.2). In other words, Cambodia and Vietnam are outliers in this relationship. Finally, most importantly, there is a moderate negative relationship between income per capita and the LFPR gap in the region. It would mean that countries with relatively higher income level would tend to have a lower difference between male and female LFPR. In other words, relatively wealthy ASEAN countries offer more equal job opportunities for male and female workers. Three CLMV countries, namely Lao PDR, Cambodia and Vietnam are outliers in this relationship. These countries are relatively poor among ASEAN countries; however, these countries have a smaller gender gap in the LFPR.
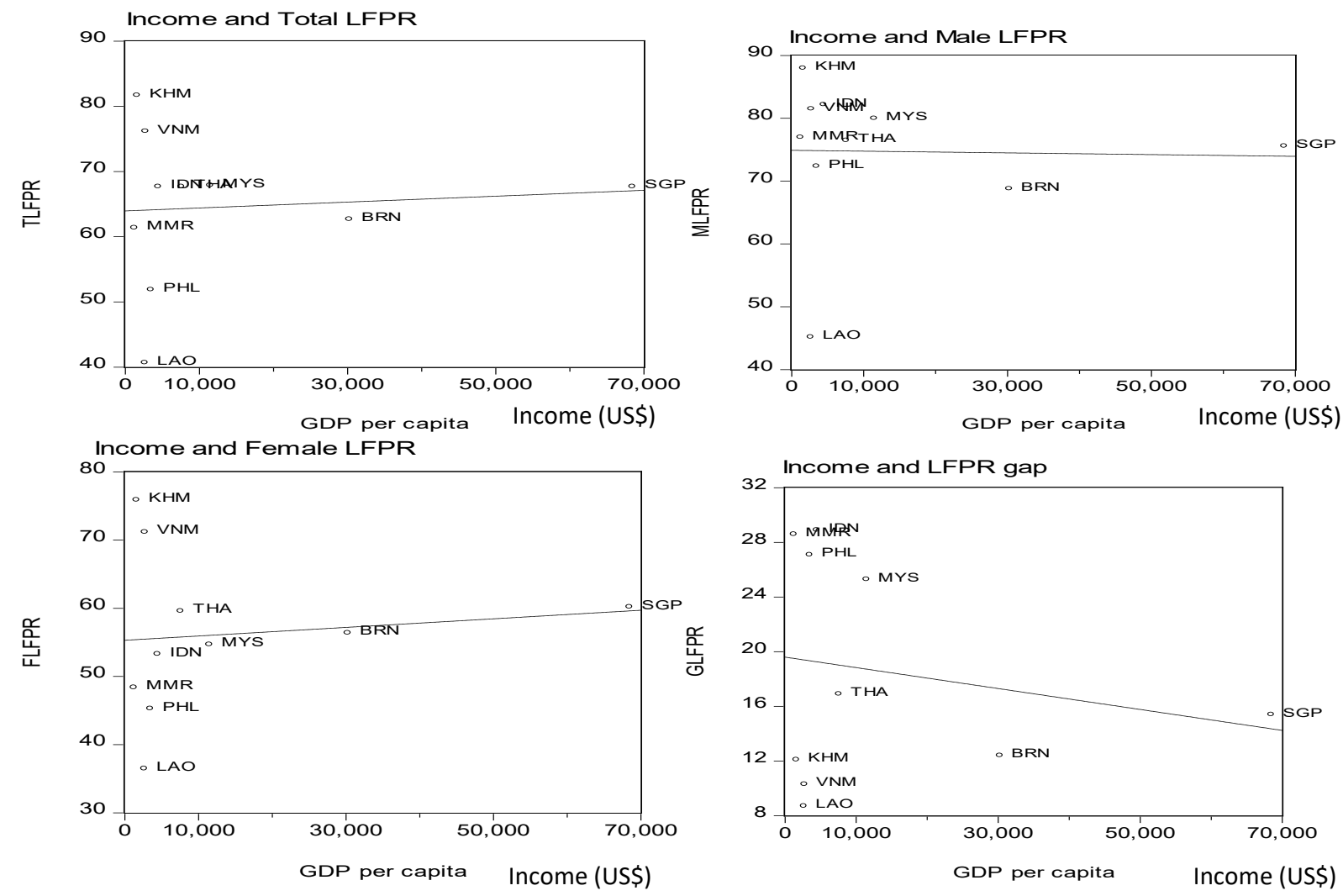

Figure 2: Labour force participation rate and income level 
Table 4 reports three types of labour force participation rate (LFPR) separated by different education level, namely the LRPR (Basic education), the LFPR (Intermediate education), the LFPR (Advanced education). The basic education level means primary and lower secondary education and advanced education level means degree. The intermediate is in-between of two categories. There are no statistical data on the topic in Singapore which is excluded from this analysis. There are four countries in which there is a positive relationship between the LFPR and education level, namely Brunei, Indonesia, Lao and Thailand. In these countries, workers with higher education would have a higher likelihood to join the labour force. There are two countries whose workers with intermediate education level would have the highest level of the LFPR, namely Cambodia and the Philippines. In these countries, the workers with intermediate education level would have the highest likelihood to enter the labour market. By contrast, these are three more countries whose workers with intermediate education level would have the lowest level of the LFPR, namely, Malaysia, Myanmar and Vietnam. In these three countries, the workers with intermediate education level would have the lowest likelihood to enter the labour market.

Table 4: Labour force participation (basic, intermediate and advanced education) (2020)

\begin{tabular}{|l|l|l|l|}
\hline & $\begin{array}{l}\text { Labour force } \\
\text { participation rate } \\
\text { (total) }\end{array}$ & $\begin{array}{l}\text { Labour force } \\
\text { participation rate } \\
\text { (male) }\end{array}$ & $\begin{array}{l}\text { Labour force } \\
\text { participation rate } \\
\text { (female) }\end{array}$ \\
\hline Brunei & 52.8 & 66.0 & 81.9 \\
\hline Cambodia & 81.6 & 86.1 & 79.6 \\
\hline Indonesia & 62.8 & 72.2 & 82.0 \\
\hline Lao PDR & 42.2 & 48.0 & 75.2 \\
\hline Malaysia & 69.0 & 66.9 & 69.2 \\
\hline Myanmar & 66.1 & 45.8 & 66.8 \\
\hline Philippines & 63.1 & 74.3 & 63.3 \\
\hline Thailand & 69.8 & 72.7 & 83.8 \\
\hline Vietnam & 78.3 & 76.6 & 88.3 \\
\hline Average & 65.0 & 67.6 & 76.6 \\
\hline
\end{tabular}

Notes: Basic education is primary and lower secondary education, Intermediate education is upper secondary and diploma and advanced education is degree

Source: World Bank (2020)

Figure 3 depicts the relationship between income per person and three types of the LFPR by education level, namely LFPR at the basic education level, LFPR at the intermediate education level and LFPR at the advanced education level. Firstly, there is a negative relationship between GDP per capita and LFPR at the basic education level in ASEAN countries. In other words, countries with lower income level would tend to have a higher LFPR at the basic education level. For example, Indonesia's LFPR at the basic education level (62.8) is relatively 
higher than LFPR at the basic education level in Brunei (52.8). There is an outlier in this negative relationship, namely Lao PDR (42.3). This country has a relatively lower income level with a lower level of LFPR at the basic education level. Secondly, there is no clear linkage between income level and LFPR at the intermediate education level. For example, some relatively poor countries tend to have higher LFPR at the intermediate education level, such as Cambodia (86.1) and Vietnam (76.6). At the same time, other relatively poor countries have lower LFPR at the intermediate education level, Myanmar (45.8) and Lao (48.0). Finally, most interestingly, there is a positive relationship between income per capita and LFPR at the advanced education level. It would imply that countries with relatively higher income level would tend to have a higher LFPR at the advanced education level. For example, LFPR at advanced education level in Brunei (81.9) is higher than LFPR at advanced education level at Lao PDR (75.2) and Cambodia (79.6).
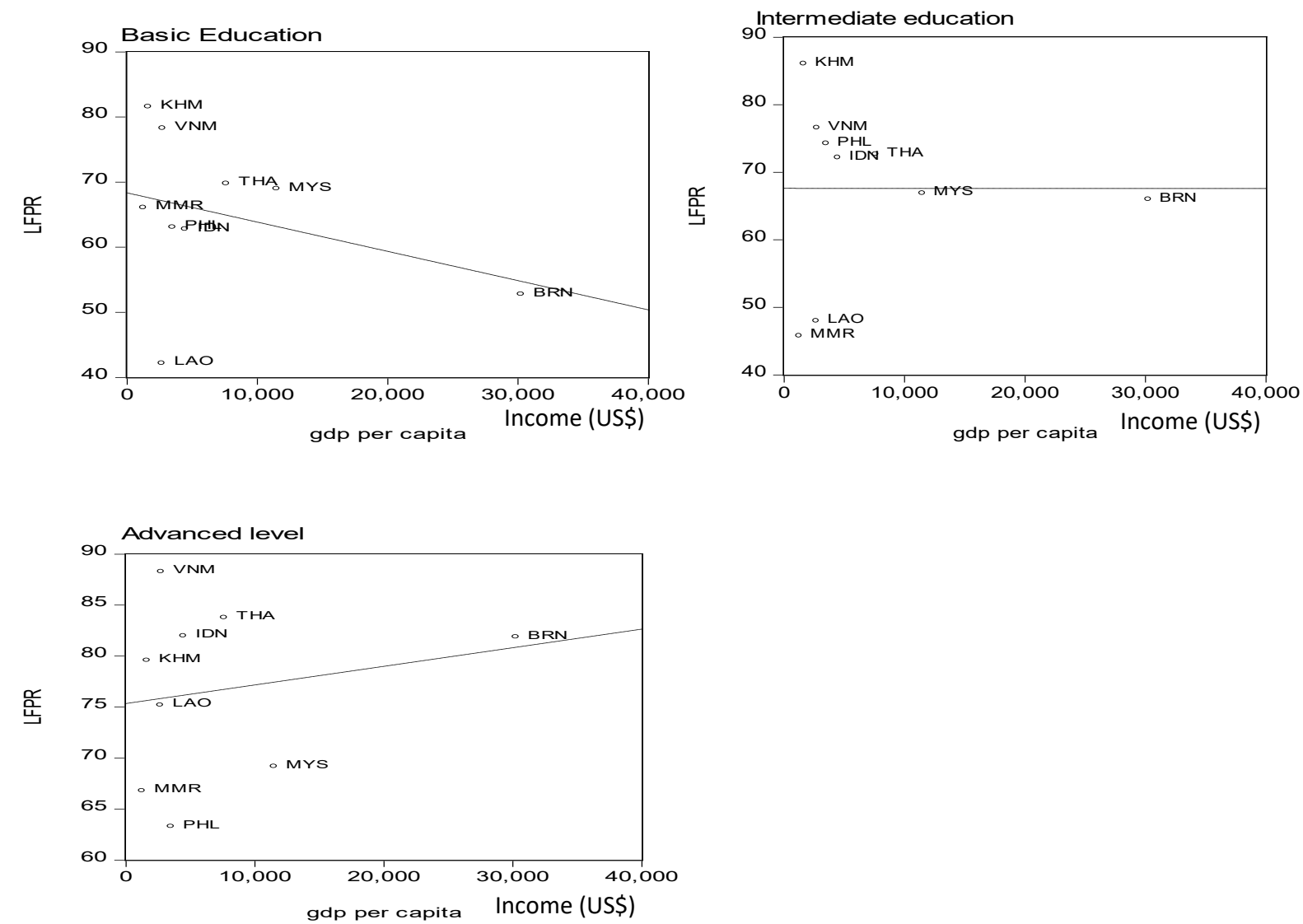

Figure 3: Labour force participation rate by education levels and income level

Table 5 reports four types of the unemployment rate, namely the total unemployment rate, the male unemployment rate, the female unemployment rate and the unemployment gap. The unemployment gap is the difference between male and female unemployment rate. Firstly, the average unemployment rate in ASEAN countries is 3.6. By contrast, there are three countries with the relatively higher total unemployment rate which are higher than 9.0, namely Brunei (9.3) and Laos (9.4). By contrast, there are three countries with the relatively lower male unemployment rate which are less than 1.0, namely Cambodia (0.7), Thailand (0.4) and 
Myanmar (0.8). Interestingly, these countries also have relatively lower inflation rates, namely Cambodia (2.4), Thailand (0.7) and Myanmar (2.8). Secondly, the average level of male unemployment rate is also 3.6. There are two countries with the relatively higher male unemployment rate which are greater than 8.0, namely Lao (10.7) and Brunei (8.7). On the other hand, there are three countries with the relatively lower male unemployment rate which are less than 1.0, namely Cambodia (0.5), Thailand (0.5) and Myanmar (0.7). Thirdly, the average level of female unemployment rate in ASEAN countries is 3.7. There are two countries with relatively higher female unemployment rate which are greater than 7.0, namely Brunei (9.9) and Lao PDR (7.8). Also, there are two countries with relatively lower female unemployment rate which is less than 1.0, namely Thailand (0.4) and Cambodia (0.8). Finally, the average level of unemployment rate gap in ASEAN countries is -0.1 . There are seven countries with negative unemployment gap, namely Brunei (-1.2), Vietnam (-1.1), Malaysia (0.8), the Philippines (-0.5), Singapore (-0.4), Cambodia (-0.3) and Myanmar (-0.3). Also, there are three countries with positive unemployment gap, namely Thailand (0.1), Lao PDR (2.9) and Indonesia (0.4).

Table 5: Unemployment rate (total, male, female and gap) (2020)

\begin{tabular}{|l|l|l|l|l|}
\hline & $\begin{array}{l}\text { Unemployment } \\
\text { rate (total) }\end{array}$ & $\begin{array}{l}\text { Unemployment } \\
\text { rate (male) }\end{array}$ & $\begin{array}{l}\text { Unemployment } \\
\text { rate (female) }\end{array}$ & $\begin{array}{l}\text { Unemployment } \\
\text { rate (gap) }\end{array}$ \\
\hline Brunei & 9.3 & 8.7 & 9.9 & -1.2 \\
\hline Cambodia & 0.7 & 0.5 & 0.8 & -0.3 \\
\hline Indonesia & 4.5 & 4.6 & 4.2 & 0.4 \\
\hline Lao PDR & 9.4 & 10.7 & 7.8 & 2.9 \\
\hline Malaysia & 3.4 & 3.1 & 3.9 & -0.8 \\
\hline Myanmar & 0.8 & 0.7 & 1.0 & -0.3 \\
\hline Philippines & 2.3 & 2.1 & 2.6 & -0.5 \\
\hline Singapore & 4.2 & 4.0 & 4.4 & -0.4 \\
\hline Thailand & 0.4 & 0.5 & 0.4 & 0.1 \\
\hline Vietnam & 1.9 & 1.8 & 2.9 & -1.1 \\
\hline Average & 3.6 & 3.6 & 3.7 & -0.1 \\
\hline
\end{tabular}

Source: World Bank (2020)

Figure 4 depicts the trend of unemployment rates for the period of 2009-2017 in six ASEAN countries, namely Cambodia, Indonesia, Malaysia, the Philippines, Singapore and Vietnam. Due to lack of sufficient data, four countries, namely Brunei, Lao PDR, Myanmar and Thailand, are excluded from this analysis. Firstly, there are two countries with relatively higher average unemployment during this period, namely Indonesia and Singapore. It is interesting to note that there is a downward movement of unemployment rates in Indonesia. The country's unemployment rate was 6.1 percent in 2009 and decreased to 5.6 percent in 2010, further to 
5.1 percent in 2011. Its unemployment rate decreased from 4.4 percent in 2012 to 4.3 percent in 2016, further to 4.1 percent in 2017. By contrast, Singapore's unemployment rate was 4.1 percent in 2010 and decreased to 3.8 percent in 2011, further to 3.7 percent in 2012. However, the country's unemployment rate increased from 3.7 percent in 2015 to 4.0 percent in 2016, further to 4.2 percent in 2017. Secondly, there are two countries with moderate level of unemployment, namely Malaysia and the Philippines. There is an interesting downward movement of unemployment rates in the Philippines. The country's unemployment rate was 3.8 percent in 2009 and decreased to 3.6 percent in 2010, further to 3.5 percent in 2011 . Also, unemployment rate in the country decreased from 3.0 percent in 2015 to 2.7 percent in 2016, further to 2.5 percent in 2017. On the other hand, Malaysia's unemployment rate was 3.6 percent in 2009 and decreased to 3.3 percent in 2010, further to 3.0 percent in 2011. However, the country's unemployment rate increased from 3.7 percent in 2015 to 4.0 percent in 2016, further to 4.2 percent in 2017. Finally, there are two more countries with relatively lower unemployment rate, namely Cambodia and Vietnam. In the case of Vietnam, the country's unemployment rate increased slightly from 1.7 percent in 2009 to 1.8 percent in 2011, further to 1.9 percent in 2011. However, the unemployment rate in Vietnam decreases from 2.1 percent in 2015 to 2.0 percent in 2017. On the other hand, Cambodia's unemployment rate decreased from 0.7 percent in 2010 to 0.5 percent in 2011 , further to 0.4 percent in 2013 . However, the country's unemployment rate increased from 0.1 percent in 2015 to 0.7 percent in 2016, further to 0.8 percent in 2017 .
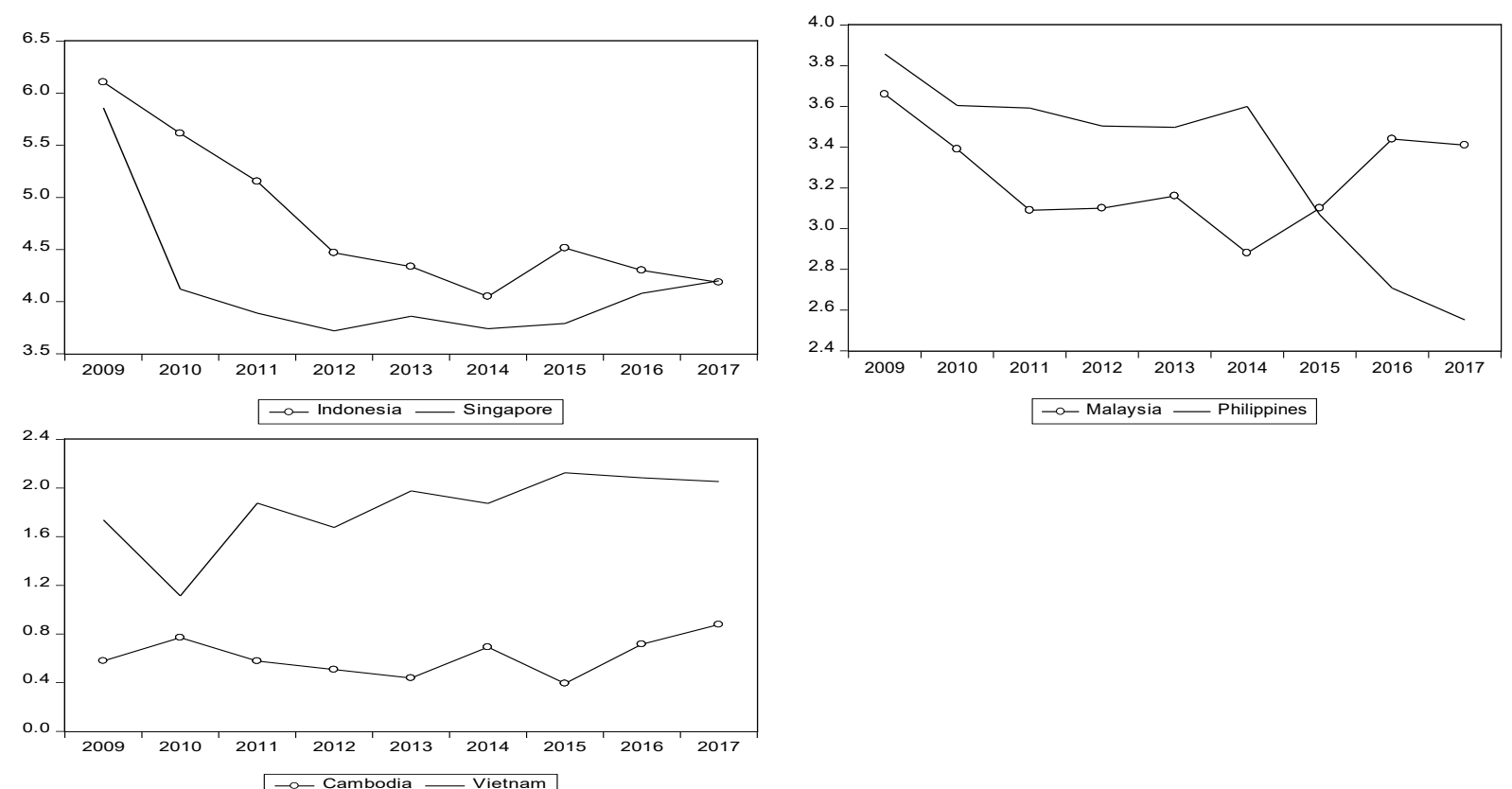

Figure 4: Unemployment rate (2009-2017) (percent)

It should be noted that difference in the relationship between income, the LFPR and the LFPR with different educational levels could be caused by discrepancies in economic structure, labour market and education policies, relatively poorer countries with low technological level, such as Cambodia and Laos, may need to use more labour, rather than physical capital, for their 
production. So, they have relatively higher level of the LFPR with basic education. By contrast, these poorer countries may lack of appropriate education policy for higher learning and labour policy for the promotion of employment among workers with the higher level of educations. These countries have relatively lower level of the LFPR with advanced level of education.

\section{The impact of COVID-19 pandemic on ASEAN's labour market}

Disruptions in the regional and global supply chain, travel bans and lockdowns due to the pandemic have had extensive repercussions on the labour market causing widespread limits on business and workplace operations. As work and business is the source of income to many, the lockdown and other containment measures have decelerated most of the economic activities in ASEAN (United Nations, 2020) affecting workers in the labour market. This includes temporary business closures as the community were forced to stay at home following quarantine orders. The most affected industry in ASEAN is travel and tourism as ASEAN relies heavily on this sector. In 2018, travel and tourism contributed 12.6 percent to the economy of ASEAN (ASEAN, 2020). However, the travel restriction and border control have restricted entry of foreigners, leading to a large drop in the number of tourists into ASEAN countries. The pandemic has not only halted the aviation industry but also impacted the tourism and hospitality related sector (ASEAN, 2020) such as hotels and restaurants due to the cancellations of tickets and room reservations (Foo, Chin, Tan, \& Phuah, 2020). As Cambodia, Thailand and Vietnam are the ASEAN countries with the largest share of employment in tourism reaching $6.7,9.0$ and $6.9 \%$ respectively (ILO, 2020a), workers in tourism-related industries in these ASEAN countries suffer most.

The repercussion of the pandemic on the labour market is reflected in the various forecasts of the impact on the regional GDP. Vietnam's GDP growth projections for 2020 is 2.7 percent from 7.0 percent in 2019 (International Monetary Fund, 2020). Similarly, GDP growth is projected to decline to 0 percent in 2020 in the ASEAN+3 (Brunei Darussalam, Cambodia, Indonesia, Myanmar, Lao People's Democratic Republic, Malaysia, Philippines, Singapore, Thailand, and Vietnam), plus China, Japan, and South Korea, from 4.8 percent in 2019. The GDP declines are more likely for Cambodia and Thailand, as these countries have very close ties with tourism and development in terms of trade services (Kimura, Thangavelu, Narjoko, \& Findlay, 2020).

In Southeast Asia, the unemployment rate has soared to almost unimaginable levels as a result of the pandemic that has ravaged economies to varying degrees. Thailand is expected to experience the worst economic downturn of any state in Southeast Asia, mainly due to its heavy reliance on global tourism. The unemployment rate in Thailand increased to 1.9 percent in August 2020 from 1\% in the same month of the previous year. It was reported that job losses in Malaysia increased by 42 percent year-on-year for the first quarter of 2020.

The lockdown efforts to mitigate the spread of the pandemic have resulted in the reduction of business operations, temporary reduction of working hours or workdays, and reduction of employees, affecting workers of all ages in the region. Such a situation may explain the reason to why certain self-employed jobs tend to increase during a crisis, as self-employment becomes a default option to many job losers for their economic survival and income (International Labour Organization, 2020). As a result, underemployment would increase on a wide scale 
although this form of coping mechanism can be limited by the restrictions on the movement of individuals.

The shock to the labour demand is also reflected in the rise of retrenchment of workers, salary reduction, revoked job offers and unpaid leave. The Malaysian Association of Hotel reported that from a total of 54,299 workers in the hotel industry in Malaysia, nearly 4 percent $(2,041$ workers) were laid off, 9 percent (5,054 workers) faced pay cut and nearly 18 percent were given unpaid leave during the MCO (Foo et al., 2020). In Vietnam, approximately 31 million employees were adversely affected by the COVID-19 pandemic, with 900,000 out of jobs and up to 18 million receiving lower income. The International Labour Organisation has predicted working hour losses where the overall reduction of working hours for the second quarter of 2020 in Southeast Asia is forecast at 12.7 percent, which is equivalent to 35 million full-time workers (ILO, 2020).

Furthermore, as job losses continue to escalate amid the pandemic, vulnerable workers such as those working in informal sectors, self-employed workers, gig workers, migrant workers, and micro, small and medium enterprises are facing a tough labour market and also at risk of losing livelihood due to lockdown. These working classes have a greater problem as they are less protected by social security schemes and other forms of income smoothing, leading to their susceptibility to the pandemic. These groups of workers and their families would have no way to live without other sources of income. Income losses and lack of income assistance in some ASEAN countries have contributed to more hardship for many informal sector workers pushing them further into working poverty as the number of hours worked falls along with decreasing economic activity (ILO, 2020c). Furthermore, households and families are in danger of being evicted, particularly when the disposal moratoriums expired, and households are struggling to pay back due rent.

The COVID-19 has also affected vulnerable and disadvantaged groups such as youth, women, and elderly depending on their condition in the labour market. Youth belongs to the age category of most vulnerable to retrenchment (ILO, 2020d; Lee, 2020). Fresh graduates will face the challenge of seeking their first job in the labour market with extremely limited demand (ILO, 2020d). The effect of the pandemic would be greater for young job-seekers as they would have a reduced "wage reservation," which is the lowest salary at which a worker will be able to accept a certain form of work - relative to experienced workers (Lee, 2020). A high proportion of women were found in the informal sector, particularly in ASEAN's low and middle-income countries. Unregistered jobs make up an estimated 78 percent of Southeast Asia's total workforce, while women make up the bulk of the informal sector in Myanmar, Lao PDR, Cambodia, Philippines, and Indonesia. Part of the gender gap is explained by the existence of the shock and the disproportionate effect on employment and industries in which more women are working (Alon, Doepke, Olmstead-Rumsey, \& Tertilt, 2020). Therefore, women are less likely to withstand economic shocks than men (WTO, 2020).

Nevertheless, COVID-19 is reshaping ASEAN's digital landscape in the labour market by bringing about significant change in the way of how work is done during the time of crisis as the pandemic has forced company and organisations to adopt remote work or work from home (WFH). As workers could abide by the social distancing while working, teleworking will 
become a new norm in ASEAN, with most corporations resorting to flexible work arrangements for its employees and at the same time promoting a positive family and work life balance. As the Southeast Asians are considered the world's most active internet users (OECD, 2019), the advancement of the digital economy has led to the rise in the usage of telemedicine, digital learning in the education system and e-commerce during the pandemic. For instance, Indonesia, Vietnam, and Singapore saw traffic increase by more than 10 percent on ecommerce platforms during the COVID-19 crisis (Dezan Shira \& Associates, 2020) when more people engaged in online shopping compared to the conventional shopping as people are instructed to stay at home and avoid crowds throughout the MCO.

\section{Conclusion}

COVID-19 which has been discovered in Wuhan, China has led to a global economic downturn. This paper examines the impact of COVID-19 pandemic on the economy focusing on the ASEAN labour market. A glance into the general characteristics of the labour market in ASEAN countries showed that there is a positive relationship between income per capita and LFPR at the advanced education level. It would imply that countries with relatively higher income level would tend to have a higher LFPR at advanced education level. The pandemic has caused an unprecedented reduction in economic activity and working time. Income support for workers and businesses operating in the informal economy is crucial in order to prevent them from falling far deeper into poverty. Business and job protection should concentrate on the most vulnerable in order to reduce the economic and social effects of the confinement process. Given the growing dependency on work from home connectivity during the pandemic and the need for ASEAN countries to further develop their e-commerce, this sector would require significant foreign investment to ensure that digital technologies can be properly leveraged in the fight to preserve business continuity. Labour experts believe that the economic and labour market situations will deteriorate even more over the next few months. Though as the situation persists, ASEAN countries have been quick to prepare their COVID-19 stimulus and relief programmes. However, the feasibility of interventions to target disadvantaged groups and the government's ability to sustain fiscal expansion would also remain a concern. ASEAN and governments all over the world find it difficult to strike the right balance between caution in protecting national health and the reopening of economic activities as the spread of COVID19 is unlikely to subside completely in the near future (ILO, 2020b).

\section{References}

Alon, T., Doepke, M., Olmstead-Rumsey, J., \& Tertilt, M. (2020). This time it's different: The role of women's employment in a pandemic recession. NBER Working Paper Series No. 27660, 1-62. https://doi.org/10.1017/CBO9781107415324.004

ASEAN. (2020). Economic Impact of COVID-19 Outbreak on ASEAN. In ASEAN Policy Brief. Retrieved from https://asean.org/storage/2020/04/ASEAN-Policy-Brief-April2020_FINAL.pdf

Chinadaily. (2020, June 8). White paper - Fighting Covid-19: China in Action. Retrieved November 2020, from Chinadaily: https://covid19.chinadaily.com.cn/a/202006/08/WS5edd8bd6a3108348172515ec.html 
CSIS. (2020). Southeast Asia COVID-19 Tracker. Retrieved from https://www.csis.org/programs/southeast-asia-program/southeast-asia-COVID-19-tracker$\underline{0}$

Dezan Shira \& Associates. (2020). Business Recovery in ASEAN After COVID-19 Legal Provisions to Manage. ASEAN Briefing, (17), 1-11.

Foo, L. P., Chin, M. Y., Tan, K. L., \& Phuah, K. T. (2020). The impact of COVID-19 on tourism industry in Malaysia. Current Issues in Tourism, 1-5. https://doi.org/10.1080/13683500.2020.1777951

ILO. (2020a). COVID-19 and employment in the tourism sector: Impact and response in Asia and the Pacific. In International Labour Organization (ILO). Retrieved from https://www.ilo.org/wcmsp5/groups/public/---asia/---robangkok/documents/briefingnote/wcms_742664.pdf

ILO. (2020b). COVID-19 employment and labour market impact in Thailand. Retrieved from https://www.ilo.org/asia/publications/labour-markets/WCMS_747944/lang--en/index.htm

ILO. (2020c). Impact of the COVID-19 crisis on loss of jobs and hours among domestic workers. Retrieved from https://coronavirus.jhu.edu/

ILO. (2020d). Youth and COVID-19 Survey Report: Impacts on jobs, education, rights and mental well-being. Geneva.

International Labour Organization. (2020). ILO Monitor : COVID-19 and the world of work. Third edition. Retrieved from https://www.ilo.org/wcmsp5/groups/public/---dgreports/--dcomm/documents/briefingnote/wcms_743146.pdf

International Monetary Fund. (2020). World Economic Outlook: The Great Lockdown. Washington DC.

Kimura, F., Thangavelu, S. M., Narjoko, D., \& Findlay, C. (2020). Pandemic (COVID-19) Policy, Regional Cooperation and the Emerging Global Production Network. Asian Economic Journal, 34(1), 3-27. https://doi.org/10.1111/asej.12198

Kobierski, Ł. (2020). A White Paper on the COVID-19 fight | Warsaw Institute.

Lee, H. A. (2020). Unemployment among Malaysia's Youth: Structural Trends and Current Challenges. ISEAS - Yusof Ishak Institute, (65), 1-16.

Li, H., Liu, S. M., Yu, X. H., Tang, S. L., \& Tang, C. K. (2020). Coronavirus disease 2019 (COVID-19): current status and future perspectives. International Journal of Antimicrobial Agents, 55(5), 105951. https://doi.org/10.1016/j.ijantimicag.2020.105951

OECD. (2019). Southeast Asia Going Digital: Connecting SMEs. In OECD. Retrieved from https://www.oecd.org/going-digital/southeast-asia-connecting-SMEs.pdf

OECD. (2020). COVID-19 crisis response in ASEAN Members States. In OECD. Retrieved from http://www.oecd.org/coronavirus/policy-responses/COVID-19-crisis-response-inasean-member-states-02f828a2/

SCIO. (2020). Fighting COVID-19: China in Action. The State Council Information Office of the People's Republic of China, (June).

Sharma, A., Tiwari, S., Deb, M. K., \& Marty, J. L. (2020). Severe acute respiratory syndrome coronavirus-2 (SARS-CoV-2): a global pandemic and treatment strategies. International Journal of Antimicrobial Agents, 56(2), 106054. 
https://doi.org/10.1016/j.ijantimicag.2020.106054

Tang, KHD. (2020). Movement control as an effective measure against COVID-19 spread in Malaysia: an overview. Zeitschrift fur Gesundheitswissenschaften $=$ Journal of public health, 1-4. Advance online publication. https://doi.org/10.1007/s10389-020-01316-w

United Nations. (2020). Policy Brief: The Impact of COVID-19 on South-East Asia. In United Nations.

WHO. (2020, January 5). Pneumonia of unknown cause - China. Retrieved November 17, 2020, from World Health Organization: https:/www.who.int/csr/don/05-january-2020pneumonia-of-unkown-cause-china/en/

WTO. (2020). The economic impact of COVID-19 on women in vulnerable sectors and economies.

Zhang, H., \& Shaw, R. (2020). Identifying research trends and gaps in the context of COVID-19. International Journal of Environmental Research and Public Health, 17(10). https://doi.org/10.3390/ijerph17103370

World Bank (2020). World Development Indicators. [accessed on 1 September 2020] https://databank.worldbank.org/ 